\title{
LATIHAN SENAM OTAK UNTUK MENINGKATKAN KEMAMPUAN MEMORI JANGKA PENDEK PADA ANAK DISABILITAS INTELEKTUAL
}

\author{
Shulhan Arief Hidayat ${ }^{1 *}$, Rio Ady Erwansyah ${ }^{2}$, Aulia Nanda Lestari ${ }^{3}$ \\ ${ }^{1}$ STIKes Hutama Abdi Husada, Tulungagung, Indonesia \\ ${ }^{2}$ STIKes Hutama Abdi Husada, Tulungagung, Indonesia \\ ${ }^{3}$ SMK Kesehatan Bakti Indonesia Medika, Tulungagung, Indonesia \\ Email: ${ }^{1 *}$ shulhan@stikestulungagung.ac.id, ${ }^{2}$ rio.ady.erwansyah@ stikestulungagung.ac.id, \\ auliananda10@gmail.com \\ * corresponding author
}

\begin{abstract}
Abstrak
Anak disabilitas intelektual merupakan anak dengan kebutuhan khusus, khususnya fungsi emosi dan kognitif. Anak disabilitas intelektual ringan mempunyai kemampuan memori jangka pendek yang rendah, disebabkan karena adanya abnormalitas bagian otak, terutama pada hipokampus. Salah satu terapi untuk meningkatkan hal tersebut adalah dengan senam otak. Senam otak adalah gerakan sederhana yang digunakan sebagai stimulasi otak untuk mengoptimalkan kinerja otak besar. Tujuan penelitian ini adalah untuk mengetahui pengaruh senam otak terhadap peningkatan kemampuan memori jangka pendek pada anak disabilitas intelektual ringan. Desain penelitian ini adalah non randomized pretest-posttest design. Rancangan ini tidak menggunakan kelompok kontrol. Populasi penelitian ini adalah semua siswa SMP berjumlah 30 orang yang berada di SLB Tulungagung dengan menggunakan teknik total sampling. Penelitian ini di lakukan pada tanggal 03 Februari - 28 Februari 2020. Pengambilan data kemampuan memori jangka pendek pretest dan postest menggunakan lembar observasi, kemudian melalui pengolahan data dengan uji statistik "Paired T test" dengan $\alpha$ 0,05. Berdasarkan uji statistik "Paired T test", didapatkan nilai signifikan $(\mathrm{sig})=0.000(\mathrm{sig}<0.05)$ yang berarti $\mathrm{H}_{0}$ ditolak dan $\mathrm{H}_{1}$ diterima. Hal ini menunjukkan ada pengaruh senam otak terhadap peningkatan kemampuan memori jangka pendek pada anak disabilitas intelektual ringan, dengan frekuensi 2 kali perminggu selama 3 minggu. Disimpulkan bahwa senam otak dapat meningkatkan kemampuan memori jangka pendek pada anak disabilitas intelektual ringan. Maka dari itu, perlu penerapan senam otak secara rutin untuk membantu dalam perkembangan kognitif dan performa akademis.
\end{abstract}

Kata kunci: Senam Otak, Kemampuan Memori Jangka Pendek, Anak Disabilitas Intelektual

\begin{abstract}
Children with intellectual disabilities are children with special needs, who have major disorders of the brain. Especially cognitive and emotional functions. Children with mild intellectual disabilities have low short-term memory abilities, due to abnormalities in the brain, especially in the hippocampus. One therapy to improve this is with brain exercise. Brain exercise is a series of simple movements that are used as brain stimulation to optimize the performance of the cerebrum. The purpose of this study was to determine the effect of brain exercise on improving short-term memory abilities in children with mild intellectual disabilities. The design of this study was a nonrandomized pretest-posttest design. This design does not use a control group. The population of this research is all 30 junior high school students who are in SLB Tulungagung using total sampling technique. This research was conducted on 03 February - 28 February 2020. Data collection on the pretest and posttest short-term memory abilities used an observation sheet, then processed the data with the "Paired T test" statistical test with 0.05. Based on the statistical test "Paired T test", obtained a significant value (sig) = 0.000 (sig <0.05) which means HO is rejected
\end{abstract}


and $\mathrm{Hl}$ is accepted. This shows that there is an effect of brain exercise on increasing short-term memory abilities in children with mild intellectual disabilities, with a frequency of 2 times per week for 3 weeks. It was concluded that brain exercise can improve short-term memory skills in children with mild intellectual disabilities. Therefore, it is necessary to apply brain exercise regularly to assist in cognitive development and academic performance.

Keywords: Brain Gym, Short-Term Memory Ability, Children with Intellectual Disabilities.

\section{Pendahuluan}

Memori atau ingatan merupakan kemampuan untuk menyimpan, mempertahankan, dan untuk mengingat kembali kejadian, pengalaman, serta aktivitas yang pernah dilakukan. Memori ada beberapa macam, menurut (Cluley, 2018), memori dibagi menjadi tiga penyimpanan, pertama memori sensori, kedua memori jangka panjang, dan ketiga adalah memori jangka pendek. Ingatan jangka pendek sendiri merupakan tempat manusia menyimpan ingatan atas sesuatu yang baru saja kita alami atau kita pikirkan. Kecepatan kemampuan kognitif seseorang bergantung dari kemampuan memori jangka pendek dan akan mempengaruhi aktivitas sehari-hari baik pada orang dewasa maupun anak-anak (Goodley, Lawthom, Liddiard, \& Runswick-Cole, 2019). Anak yang mengalami perkembangan tidak normal bisa diidentifikasi sejak umur kurang dari 18 tahun. Perkembangan yang tidak normal tersebut membuat anak memerlukan perhatian dan kebutuhan khusus (Cieza, Sabariego, Bickenbach, \& Chatterji, 2018).

Anak-anak yang tergolong anak dengan kebutuhan salah satunya adalah disabilitas intelektual (Desriyani, Nurhidayah, \& Adistie, 2019). Mereka ditempatkan di sekolah khusus untuk meningkatkan perkembangan anak berkebutuhan khusus tersebut. Menurut PP No.17 pasal 133 bentuk sekolah khusus di Indonesia dikenal sebagai Sekolah Luar Biasa (SLB). Anak disabilitas intelektual merupakan salah satu anak berkebutuhan khusus dengan gangguan utama pada otak khususnya fungsi kognitif dan emosi. Retnaningsih \& Hidayat (2012) juga menyatakan bahwa dimensi perawatan utama untuk anak disabilitas intelektual adalah fungsi kognitif dan keterampilan. Anak dengan disabilitas intelektual diklasifikasikan dari IQ yang dimiliki menjadi empat tingkatan yaitu disabilitas intelektual ringan (55-70), sedang (35-54), berat (20-34),dan sangat berat $<20$.

Berdasarkan data Pusat Data dan Informasi Kementrian Kesehatan RI, 2019 tercatat jumlah penyandang disabilitas mencapai sekitar 9.046.000 jiwa dari sekitar 237 juta jiwa. Jika dikonversi dalam bentuk persen, jumlahnya sekitar 4,74\%. Hasil (Riskesdas, 2018) mendapatkan 3,3\% anak umur 5-17 tahun yang mengalami disabilitas. Sementara di Jawa Timur sendiri menunjukkan angka 3,2\% dari total keseluruhan warga Jawa Timur. Menurut Peraturan Menteri Sosial Republik Indonesia No. 30/HUK/2011 Tentang "Standar Nasional Pengasuhan Anak Untuk Lembaga Kesejahteraan Sosial Anak.," (2011), Adapun jumlah penyandang disabilitas intelektual sebesar 3,11\%, atau sebesar 6,7 juta jiwa.

Data yang diperoleh di Dinas Pendidikan Kabupaten Tulungagung (Desember, 2019), jumlah penderita disabilitas intelektual adalah 298 orang atau sebesar $10.8 \%$ dari jumlah penyandang disabilitas intelektual di Indonesia. Berdasarkan study pendahuluan yang dilakukan di SLB Tulungagung tanggal November 2019. Didapatkan data 
keseluruhan siswa yaitu sebanyak 94 siswa yang terdiri dari 49 siswa SD, 30 siswa SMP, dan 15 siswa SMA. Dengan tenaga pengajar atau guru sebanyak 12 orang. Kepala sekolah dan para guru mengatakan rata-rata dan bahkan hampir semua siswa didiknya mengalami kesulitan konsentrasi dan mengulang materi yang telah diajarkan.

Anak dengan disabilitas intelektual ringan masih memiliki kemampuan kognitif yang bisa diperbaiki dengan adanya pendidikan dan pelatihan dari pada anak disabilitas intelektual dengan klasifikasi yang lain (Desriyani et al., 2019). Yang disebut sebagai anak mampu didik atau debil. Anak disabilitas intelektual ringan memiliki hambatan dalam kemampuan memori terutama kemampuan memori jangka pendek sehingga mengalami keterbatasan dalam mengingat (Mayasari, 2019). Sedangkan kemampuan penyimpanan memori panjang pada anak disabilitas intelektual tidak berbeda dengan anak normal apabila dilakukan secara bertahap dan di ulang-ulang. Memori jangka pendek yang buruk pada anak dapat menyebabkan masalah kesehatan yaitu amnesia pada masa anak-anak, sehingga anak tidak mampu bersikap kreatif dan dapat membuat fungsi otak bertambah menurun (Damayanti, Jamilah, Suban, Fitriana, \& Alamsyah, 2020).

Implikasi untuk mengatasi hal tersebut adalah dengan terapi. Terapi yang dapat digunakan untuk anak dengan disabilitas intelektual diantaranya terapi okupasi, terapi bermain, life skill (keterampilan hidup), dan vocational therapy (terapi bekerja). Terapi okupasi dapat bermacam-macam sesuai dengan fungsinya yaitu memperbaiki aspek sensori motorik, fisik, kognitif, intrapersonal-interpersonal, perawatan diri atau Activity Daily Living (ADL), dan produktivitas. Terapi okupasi lebih diarahkan untuk membantu mengatasi permasalahan pada anak disabilitas intelektual (Azzahra, Handajani, \& Asikin, 2016).

Stimulasi otak sangat penting untuk meningkatkan perkembangan pada anak dengan disabilitas intelektual secara maksimal sehingga terapi okupasi yang dapat diterapkan adalah terapi okupasi kognitif, terapi ini terbukti dapat meningkatkan kemampuan anak dalam hal ingatan jangka pendek. Terapi okupasi kognitif adalah terapi yang menggunakan beberapa gerakan yang mudah diikuti anak dan dapat digunakan untuk mengoptimalkan kinerja otak. Terapi okupasi kognitif yang bisa digunakan adalah senam otak (Waiman, Soedjatmiko, Gunardi, Sekartini, \& Endyarni, 2016). Pembelajaran pada anak disabilitas masih belum mengaplikasikan stimulasi untuk otak padahal dengan stimulasi otak yang terus-menerus dapat meningkatkan fungsi kognitif karena otak memiliki sifat yang dinamis dimana plastisitas otak bisa berkembang sesuai dengan stimulus yang diberikan oleh lingkungannya (Cluley, 2018). Pemberian terapi yang diberikan secara terus-menerus pada otak melalui gerakan senam otak dapat membuat struktur otak berubah secara signifikan, hubungan antar neuron lebih banyak, sel glia yang menyokong fungsi neuron bertambah, kapiler-kapiler darah yang menyuplai darah dan oksigen ke otak menjadi lebih banyak (Rafitaka, Karini, \& Supratiwi, 2018).

\section{Metode Penelitian}

Jenis penelitian yang dilakukan pada penelitian saat ini adalah penelitian quasy eksperimental dengan rancangan non randomized pretest-posttest design. Rancangan ini tidak menggunakan kelompok kontrol. Populasi dalam penelitian ini adalah semua siswa 
SMP disabilitas intelektual ringan yang berjumlah 30 di SLB Tulungagung. Dengan total sampling dalam satu kelas didapatkan sampel berjumlah 30 siswa.

Instrumen dalam penelitian ini adalah lembar observasi baku yaitu berupa instrumen dari Wechsler Intelligence Scale for Children-Fourth Edition (WISCIV) yang terdiri dari digit forward. Digit forward menghitung jumlah digit dalam seri yang bisa diingat dan diucapkan oleh responden dengan urutan digit dari depan ke belakang setelah 30 detik. Penilaian hasil pengukuran dilakukan melalui dua tahap. Pertama, pemberian tanda cek $(\sqrt{ })$ pada seri yang bisa diucapkan dengan benar dari digit forward. Kedua, dengan menentukan jumlah digit dalam seri yang terakhir bisa diingat dan diucapkan oleh anak disabilitas intelektual ringan. Data yang diperoleh dari hasil pengukuran dianalisis dengan menggunakan uji- $t$ (beda) berpasangan (paired $t$-test) dengan taraf signifikasi $5 \%$.

\section{Hasil dan Pembahasan}

\section{Hasil}

1. Distribusi Frekuensi Memori Jangka Pendek Anak Sebelum Diberikan Senam Otak

Tabel 1. Distribusi Frekuensi Memori Jangka Pendek Anak Sebelum Diberikan Senam Otak

\begin{tabular}{|c|c|c|}
\hline $\begin{array}{c}\text { Kemampuan Memori } \\
\text { Jangka Pendek }\end{array}$ & $\mathbf{F}$ & Prosentase $(\%)$ \\
\hline Kurang & 1 & $3,3 \%$ \\
\hline Cukup & 25 & $83,4 \%$ \\
\hline Baik & 4 & $13,3 \%$ \\
\hline Jumlah & 30 & $100 \%$ \\
\hline
\end{tabular}

Berdasarkan tabel 1 diketahui bahwa dari 30 responden sebelum diberikan senam otak hamper seluruhnya dari responden memiliki memori jangka pendek yang cukup yaitu sebanyak 25 responden dengan prosentase $83,4 \%$.

\section{Distribusi Frekuensi Memori Jangka Pendek Anak Sesudah Diberikan Senam Otak}

Tabel 2. Distribusi Frekuensi Memori Jangka Pendek Anak Sesudah Diberikan Senam Otak

\begin{tabular}{|c|c|c|}
\hline $\begin{array}{c}\text { Kemampuan Memori } \\
\text { Jangka Pendek }\end{array}$ & $\mathbf{F}$ & Prosentase $(\%)$ \\
\hline Kurang & 0 & $0 \%$ \\
\hline Cukup & 20 & $66,6 \%$ \\
\hline Baik & 10 & $33,4 \%$ \\
\hline Jumlah & 30 & $100 \%$ \\
\hline
\end{tabular}


Berdasarkan tabel 2 diketahui bahwa dari 30 responden, sesudah diberikan senam otak sebagian kecil dari responden yang memiliki kemampuan memori jangka pendek cukup yaitu sebanyak 20 responden dengan prosentase $66,6 \%$.

\section{Distribusi Frekuensi Memori Jangka Pendek Anak Sebelum Dan Sesudah Diberikan Senam Otak}

Tabel 3. Distribusi Frekuensi Memori Jangka Pendek Anak Sebelum Dan Sesudah Diberikan Senam Otak

\begin{tabular}{lcccc}
\hline \multicolumn{1}{c}{$\begin{array}{c}\text { Kemampuan } \\
\text { Memori Jangka }\end{array}$} & Pre & Post & \\
\cline { 2 - 5 }$\quad$ Pendek & $\mathrm{F}$ & $\%$ & 0 & $\%$ \\
\hline Kurang & 1 & $3,3 \%$ & 20 & $0 \%$ \\
Cukup & 25 & $83,4 \%$ & 10 & $66,6 \%$ \\
Baik & 4 & $13,3 \%$ & 30 & $100 \%$ \\
\hline \multicolumn{1}{c}{ Jumlah } & 30 & $100 \%$ & & \\
\hline $\mathrm{P}$ value $=0,000, \alpha=0,05$ & & & & \\
\hline
\end{tabular}

Berdasarkan tabel 4.5 diketahui bahwa dari 30 responden, sebelum diberikan senam otak hamper seluruhnya dari responden memiliki kemampuan memori jangka pendek yang cukup yaitu sebanyak 25 responden dengan prosentase 83,4\%. Sedangkan sesudah diberikan senam otak sebagian besar responden memiliki kemampuan memori jangka pendek yang cukup yaitu sebanyak 20 responden dengan prosentase $66,6 \%$.

Melalui data hasil pre tes (sebelum) dilakukan intervensi senam otak, dan di bandingkan dengan data dari hasil post test (sesudah) di lakukan senam otak, data dianalisis dengan sistem komputerisasi yaitu SPSS. Menggunakan uji Paired T test, di dapat nilai signifikan $(\mathrm{sig})=0.000(\mathrm{sig}<0.05)$, yang berarti H0 ditolak dan $\mathrm{H} 1$ diterima. Hal ini menunjukkan ada pengaruh senam otak terhadap peningkatan kemampuan memori jangka pendek pada anak disabilitas intelektual ringan.

\section{Pembahasan}

\section{Memori Jangka Pendek Pada Anak Disabilitas Intelektial Di SLB Tulungagung Sebelum Diberikan Intervensi}

Diketahui bahwa dari 30 responden sebelum diberikan intervensi senam otak hampir seluruhnya dari responden memiliki memori jangka pendek yang cukup yaitu sebanyak 25 responden dengan prosentase $83,4 \%$.

Memori atau daya ingat adalah kemampuan seseorang untuk menyimpan suatu informasi dan informasi tersebut dapat dipanggil kembali untuk digunakan beberapa waktu kemudian. Memori adalah unsur inti dari perkembangan kognitif karena memori diperlukan dalam segala bentuk proses belajar (Simpson, Mizen, \& Cooper, 2020). Patel mendefinisikan pengertian memori jangka pendek merupakan 
kemampuan seseorang untuk menyimpan informasi selama, kira-kira selama 30 detik (Patel, Cabral, Ho, \& Merrick, 2020).

Stimulasi disertai aktivitas fisik dapat meningkatkan neurogenesis sel-sel di gyrusdentata hippocampus, meningkatkan kinerja hippocampus pada proses belajar, sehingga secara otomatis dapat memperkuat daya inngat dan dapat meninngkatka kemampuan memori jangka pendek pada anak (Desriyani et al., 2019). Ada beberapa intervensi yang dapat dilakukan untuk memperkuat ingata jangka pendek anak yaitu terapi okupasional kognitif (senam otak), terapi gelombang otak, terapi musik klasik, aromaterapi, terapi latihan mental seperti bermain catur dan kartu, dan The brain training revolution (Bailey, 2013). Anak dengan disabilitas intelektual masih memiliki hambatan dalam kemampuan memori terutama kemampuan memori jangka pendek sehingga mengalami keterbatasan dalam mengingat (Simpson et al., 2020). Implikasi untuk mengatasi hal tersebut adalah dengan terapi. Salah satunya dengan terapi okupasi kognitif yang lebih diarahkan untuk membantu mengatasi permasalahan pada anak disabilitas intelektual (Parrini et al., 2017).

Dengan hasil yang didapatkan diatas, sejalan dengan fakta dan teori bahwa memori atau daya ingat anak disabilitas dapat diperkuat dengan cara pemberikan bimbingan dan pendidikan yang baik. Serta pemberian intervensi berupa terapi okupasional kognitif (senam otak).

\section{Memori Jangka Pendek Pada Anak Disabilitas Intelektial Di SLB Tulungagung Sesudah Diberikan Intervesi}

Diketahui bahwa dari 30 responden, sesudah diberikan intervensi (senam otak) sebagian kecil dari responden yang memiliki kemampuan memori jangka pendek cukup yaitu sebanyak 20 responden dengan prosentase $66,5 \%$.

Derajat disabilitas intelektual berbanding lurus dengan kemampuan mengingat., pangkal utama dari kelemahan daya ingat pada anak disabilitas intelektual ringan sangat erat dengan perhatian dan konsentrasi, sehingga anak disabilitas intelektual ringan tidak mudah untuk fokus dan mengikuti stumulus yang diberikan (Hidayat, Hartini, \& Wahyuni, 2021). Kesulitan yang dialami anak disabilitas intelektual ringan ketika mengingat ada pada kemampuan dalam merekonstruksi ingatan. Seorang penelitian menyebutkan bahwa saat ada stimulasi maka struktur otak anak berubah secara dramatis, hubungan antarneuron lebih banyak, sel glia yang menyokong fungsi neuron bertambah, dan kapiler-kapiler darah yang menyuplai oksigen dan darah ke otak menjadi lebih padat (Sutinah, 2019). Parrini meneliti manfaat latihan fisik dan menemukan bahwa konsentrasi dan fokus mental anak-anak meningkat sesudah melakukan aktivitas fisik yang terstruktur. Latiha-latihan ini mempunyai efek pada lobus frontalis otak yang berguna untuk konsentrasi mental, perencanaan, dan pengambilan keputusan. Penemuan itu sejalan dengan pendapat presiden Council of Fitness bahwa melakukan aktivitas fisik 30 menit setiap hari dapat menstimulasi otak (Parrini et al., 2017).

Menurut peneliti, sejalan dengan fakta dan teori diatas bahwa latihan dengan gerakan sederhana berhasil merangsang kerja sama antara keseluruhan bagian otak 
sehingga fungsi semua area otak akan meningkat. Kapasitas memori jangka pendek sangat bergantung pada usia. Semakin tinggi usia, semakin besar kapasitas memori ini. Pada usia 3 tahun, seorang anak memliki satu kapasitas memori jangka pendek. Jadi memori jangka pendek pada usia dewasa mempunyai kapasitas yang terbatas yaitu lima sampai sembilan item informasi yaitu hanya bisa berpikir antara lima sampai sembilan hal yang berbeda selama kurang lebih 15 hingga 30 detik (Musdalifah, 2020). Kemampuan otak anak akan menurun jika jarang digunakan (memori jangka pendek anak), namun kemampuan memori jangka pendek dapat meningkat kembali salah satunya dengann cara melakukan senam otak setiap hari. Sebab senam otak merangsang dan juga merelaksasikan keseluruhan bagian otak (Effendy, Prasanty, \& Utami, 2019).

\section{Pengaruh Senam Otak Terhadap Peningkatan Memori Jangka Pendek Pada Anak Disabilitas Intelektial Ringan}

Didapatkan hasil bahwa sebagian besar responden mengalami peningkatan kemampuan memori jangka pendek. Dimana dengan uji Paired T Test, bahwa dari 30 responden yang mengalami peningkatan sebanyak 26 responden (86.67\%), sedangkan yang tidak mengalami peningkatan (tetap) sebanyak 4 responden (13.33\%). Dan di dapat nilai signifikan (sig) yaitu 0.000 (sig < 0.05 ) yang berarti $\mathrm{H}_{0}$ ditolak dan $\mathrm{H} 1$ diterima. Hal ini menunjukkan bahwa adanya pengaruh yang signifikan.

Hasil penelitian sesuai dengan penelitian lain yang menjelaskan bahwa senam otak dapat merangsang dan merelaksasikan otak serta merangsang sistem yang terkait dengan perasaan atau emosi (Damayanti et al., 2020). Penelitian (Effendy et al., 2019) menggunakan gerakan senam otak dalam sekolah anak dengan kebutuhan khusus yaitu Sindrom Angelman, ADHD, dimana gerakan senam otak disesuaikan dengan kebutuhan dan kemampuan para murid dan setelah dilakukan intervensi senam otak didapatkan perbaikan yang nyata dalam fungsi kognitif. Hal ini juga sejalan dengan penelitian Rafitaka, dalam penelitiannya menemukan bahwa setelah dilakukan senam otak selama 6-8 kali dengan intensitas dua kali seminggu, anak dengan autisme yang awalnya hanya mampu berkata 2 kata dapat melakukan pidato dengan lancar (Rafitaka et al., 2018).

Dari hasil yang didapatkan di atas, maka peneliti mengambil kesimpulan bahwa terapi okupasi kognitif yaitu pemberia latihan senam otak secara rutin mampu meningkatkan kemampuan dan memperkuat ingatan jangka pendek pada anak disabilitas intelektual ringan dengan frekuensi 6 kali dengan rincian terapi dilakukan dalam 3 minggu dan 1 minggunya diberikan 2 kali.

\section{Kesimpulan}

Berdasarkan hasil penelitian pengaruh senam otak (Brain Gym) terhadap peningkatan kemampuan memori jangka pedek pada anak disabilitas intelektual ringan di SLB Tulungagung Tahun 2020, dan hasil analisis dari uji satistik menggunakan Paired T Test, dengan tingkat signifikan $\alpha=0,05$, didapatkan hasil nilai signifikan (sig) $=0.000$ $($ sig $<0.05)$ hipotesis diterima yang artinya ada pengaruh. Senam otak terbukti 
meningkatkan kemampuan memori jangka pendek yang semula dari 30 responden sebelum diberikan senam otak, terdapat 1 responden memiliki kemampuan memori jangka pendek yang kurang, 25 responden memiliki kemampuan memori jangka pendek yang cukup, dan 4 responden lainnya memiliki kemampuan memori jangka pendek yang baik. Setelah diberikan senam otak, terdapat peningkatan pada kemampuan memori jangka pendek. 20 responden memiliki kemampuan memori jangka pendek yang cukup, dan 10 responden lainnya memiliki kemampuan memori jangka pendek yang baik.

\section{Referensi}

Azzahra, A. V., Handajani, R. P., \& Asikin, D. (2016). Ruang Terapi Okupasi Activities of Daily Living (ADL) Anak Tunadaksa Dengan Pendekatan Klasifikasi Gangguan. Jurnal Mahasiswa Jurusan Arsitektur Universitas Brawijaya, 4(1).

Bailey, S. (2013). Review of The brain training revolution: A proven workout for healthy brain aging. Activities, Adaptation \& Aging, 37(3).

Cieza, A., Sabariego, C., Bickenbach, J., \& Chatterji, S. (2018). Rethinking Disability. BMC Medicine, 16(1). https://doi.org/10.1186/s12916-017-1002-6

Cluley, V. (2018). From "Learning disability to intellectual disability"-Perceptions of the increasing use of the term "intellectual disability" in learning disability policy, research and practice. British Journal of Learning Disabilities, 46(1). https://doi.org/10.1111/bld.12209

Damayanti, E., Jamilah, Suban, A., Fitriana, \& Alamsyah, N. (2020). The Role Of Brain Gym In Improving The Short-Term Memoryfunction To Children. Al Asma: Journal of Islamic Education, 2(2), 247-254.

Desriyani, Y., Nurhidayah, I., \& Adistie, F. (2019). Burden of Parents in Children with Disability at Sekolah Luar Biasa Negeri Cileunyi. NurseLine Journal, 4(1). https://doi.org/10.19184/nlj.v4i1.8696

Effendy, E., Prasanty, N., \& Utami, N. (2019). The effects of brain gym on quality of sleep, anxiety in elderly at nursing home care case Medan. Open Access Macedonian Journal of Medical Sciences, 7(16). https://doi.org/10.3889/oamjms.2019.397

Goodley, D., Lawthom, R., Liddiard, K., \& Runswick-Cole, K. (2019). Provocations for Critical Disability Studies. Disability and Society, 34(6). https://doi.org/10.1080/09687599.2019.1566889

Hidayat, S. A., Hartini, S., \& Wahyuni, B. (2021). Factors Related With Sexual Behavior In Intellectual Disabilities In SLB (Special Needs School) Districts Of Bantul, Yogyakartan. The Malaysian Journal of Nursing, 12(4). https://doi.org/10.31674/mjn.2021.v12i04.012

Mayasari, N. (2019). Layanan Pendidikan bagi Anak Tunagrahita denganTipe Down Syndrome. Jurnal Studi Islam, Gender Dan Anak, 14(1), 111-134. https://doi.org/10.24090/yinyang.v14i1.2019.pp111-134

Menteri Sosial Republik Indonesia. Peraturan Menteri Sosial Republik Indonesia No. 30/HUK/2011 tentang "Standar Nasional Pengasuhan Anak Untuk Lembaga Kesejahteraan Sosial Anak.”, (2011). Indonesia.

Musdalifah, R. (2020). Pemrosesan dan Penyimpanan Informasi pada Otak Anak dalam Belajar: Short Term and Long Term Memory. AL-ISHLAH: Jurnal Pendidikan Islam, 17(2). https://doi.org/10.35905/alishlah.v17i2.1163

Parrini, M., Ghezzi, D., Deidda, G., Medrihan, L., Castroflorio, E., Alberti, M., ... Contestabile, A. (2017). Aerobic exercise and a BDNF-mimetic therapy rescue 
learning and memory in a mouse model of Down syndrome. Scientific Reports, 7(1). https://doi.org/10.1038/s41598-017-17201-8

Patel, D. R., Cabral, M. D., Ho, A., \& Merrick, J. (2020). A clinical primer on intellectual disability. Translational Pediatrics, 9. https://doi.org/10.21037/TP.2020.02.02

Pusat Data dan Informasi Kementrian Kesehatan RI. (2019). Situasi Disabilitas. In Pusat Data dan Informasi Kementrian Kesehatan RI.

Rafitaka, A., Karini, S. M., \& Supratiwi, M. (2018). Pengaruh Pelatihan Brain Gym Terhadap Peningkatankemampuan Konsentrasi Pada Anak Attention Deficit Hyperactivity Disorder (ADHD). Jurnal Psikohumanika, 10(2). https://doi.org/10.31001/j.psi.v10i2.309

Retnaningsih, I., \& Hidayat, R. (2012). Representasi Sosial tentang Disabilitas Intelektual pada Kelompok Teman Sebaya. Jurnal Psikologi, 39(1).

Riskesdas. (2018). Laporan Nasional Riskesdas 2018. In Badan Penelitian dan Pengembangan Kesehatan.

Simpson, N., Mizen, L., \& Cooper, S. A. (2020). Intellectual disabilities. Medicine (United Kingdom), Vol. 48. https://doi.org/10.1016/j.mpmed.2020.08.010

Sutinah, S. (2019). Terapi Bermain Puzzle Berpengaruh Terhadap Kemampuan Memori Jangka Pendek Anak Tunagrahita. Jurnal Endurance, 4(3). https://doi.org/10.22216/jen.v4i3.4385

Waiman, E., Soedjatmiko, S., Gunardi, H., Sekartini, R., \& Endyarni, B. (2016). Sensori Integrasi: Dasar dan Efektivitas Terapi. Sari Pediatri, 13(2). https://doi.org/10.14238/sp13.2.2011.129-36 